Article

\title{
Industrial Policy in the EU and Its Neighbourhood: Learning from Policy Experimentation
}

\author{
Maximilian Benner \\ European Commission, Joint Research Centre (JRC), 41092 Seville, Spain; maximilian.benner@ec.europa.eu; \\ Tel.: + 34-954-487-113
}

Received: 1 April 2019; Accepted: 8 May 2019; Published: 10 May 2019

\begin{abstract}
Newer approaches of industrial policy that focus on catalytic and facilitating interventions of government have become a rivalling model to neoclassical laissez-faire approaches. Inspired by the success stories of East Asian newly industrialised economies (NIEs), newer approaches advocate a more experimental policy stance. Newer industrial policies, including the concept of the "entrepreneurial state", call upon governments to play a catalytic and facilitating role in increasing innovation and, thus, economic growth. During the past three decades, countries have experimented with some of these new approaches, and so has the European Union (EU). Currently, two major policy frameworks of the EU, Horizon 2020 and smart specialisation, shape the European approach to industrial policy and are gaining in importance for enlargement and neighbourhood countries, too. At the same time, these countries outside the EU have pursued their own experiments in industrial policy. The article argues that to better understand what contributes to the success or failure of industrial policies, learning from experiences made both by the EU and its neighbours is valuable. The article draws conclusions from three countries in the EU's neighbourhood, Israel, Tunisia, and North Macedonia. In particular, the article examines the role EU approaches and programs, such as smart specialisation or Horizon 2020, can play in anchoring more entrepreneurial industrial policies in enlargement and neighbourhood countries and addresses problems to be expected when governments are to engage in policy experimentation.
\end{abstract}

Keywords: industrial policy; entrepreneurial state; innovation; EU; smart specialisation; Horizon 2020

JEL Classification: L53; O14; O38

\section{Introduction ${ }^{1}$}

Industrial policy reflects the large trends in economic thinking probably more than most other fields of economic policy. Although industrial policy can be traced across former centuries and policy stances, such as mercantilism or Muhammad Ali's state-led industrialisation of Egypt, classical industrial policy is arguably most closely linked to import-substituting industrialisation and accompanying infant-industry protection popular among industrialising countries during the 1950s and 1960s, as well as the drive to "pick winners" among firms, technologies, or industries and to build "national champions" found in industrialised and industrialising countries alike at the time (Landesmann 2015; Rodrik 2009; Waterbury 1999).

Later, during the 1970s and 1980s, as monetarism and neoclassical theories became the rising tide in economic discourse and laissez-faire policies grew dominant (Page 2015, p. 153), the term industrial

1 The views expressed are purely those of the author and may not in any circumstances be regarded as stating an official position of the European Commission. 
policy became unpopular. The failures of traditional industrial policies such as import-substituting industrialisation (Waterbury 1999) certainly contributed to this change in perception but, interestingly, the changing climate of economic policy and discourse did not mean governments actually stopped implementing targeted policies to promote industrialisation and structural change (Landesmann 2015, p. 133).

In the 1990s, the perception of industrial policy changed again. Apart from the growing acknowledgement that neoclassically inspired laissez-faire policies may have responded to macro-level stabilisation needs but not to more comprehensive structural development needs, the emergence of East Asian newly industrialised economies (NIEs), the so-called "tigers" (Hong Kong, Singapore, Taiwan, South Korea) and, later, China, suggested that a mix of industrial policy, selective openness to trade and investment, and macro-level stability might be more conducive to industrialisation than pure market liberalisation (Chen et al. 2001; Chiu and Lui 2001; Chu et al. 2001; Kang 2001; Wong 2001; Wong and Ng 2001; World Bank 1993). The new generation of industrial policies came under different names and from different origins. One of the most influential inspirations for economic policymakers during the 1990s was Porter's (Porter 1990) work on industrial clusters that kicked off a wave of cluster policies in many countries across the world. Based on microeconomic thinking and the critical role of inter-firm rivalry, (Porter 1990) offered a rationale for targeted policies to promote specific industries systemically, not by protecting them from competition but, rather, by exposing it to competition. In contrast to classical industrial policies, the new generation of industrial policies did not strive to limit competition but drew instead on the dynamic benefits of competitive markets. Consistently, industrial policy became increasingly linked with innovation and entrepreneurship policies. Mazzacato's (Mazzucato 2011, 2013, 2015) reasoning on the "entrepreneurial" role of the state in innovation illustrates the point well.

Today, there seems to be a growing body of literature that stresses the role of industrial policies for economic development. As (Rodrik 2009) argues, similar to widely acknowledged fields of government action such as education or health, the question should not be if governments should engage in industrial policy, but how. East Asian NIEs illustrate this point well due to the contribution of industrial policies to their economic development, but other historical examples such as Japan, Germany, or Mexico underscore the role of various kinds of industrial policies for industrialisation (e.g., Fernández Cuesta 2019, pp. 242-47; Waterbury 1999).

On the policy side, the European Union (EU) offers an interesting case for the change in perception industrial policies faced. Given different traditions of economic policy among member states (for instance, between France's traditional "national champions" policies and Germany's ordo-liberal tradition), on the EU level there was both a chance and a need to develop a new and overarching vision of targeted policies to drive structural change, i.e., industrial policy. Consequently, a debate has emerged on how the EU should promote the innovative upgrading of its economy in targeted ways and linked to the objectives of its "Europe 2020" strategy (European Commission 2010c) with its high relevance for industrial policy (e.g., Mazzucato 2015; Page 2015; Pianta 2015). In 2017 the European Commission published its industrial policy strategy that described the relationships between the policy objectives of smart, inclusive and sustainable growth on the one hand and targeted support through policy frameworks, such as the smart specialisation approach and the research and innovation (R and I) framework programme "Horizon 2020" on the other hand (European Commission 2017). The remarkable thing is that the explicit reference to industrial policy has become accepted again and is used today to describe a broader, more comprehensive, systemic, and dynamic set of policy interventions than it used to, and goes hand-in-hand with supporting innovation.

Given the economic interrelationships between the EU and its neighbourhood and the Europe's economic and strategic interest to contribute to the vision of a prosperous Mediterranean, it is worthwhile to ask how newer trends in EU industrial policy (including innovation and regional policy) can contribute to long-term economic development in enlargement and neighbourhood countries. This is the principal question the present article addresses. By embedding current EU policies in the 
long-term debate on industrial policy and looking at opportunities for enlargement and neighbourhood countries to benefit from the EU's experience (and vice versa) and to cooperate under the umbrella of EU programmes, the article seeks to draw conclusions for how to relate neighbouring countries' policies with the EU's ongoing quest for ever more effective industrial policy frameworks.

The article is structured as follows. The first section provides a brief overview of the long-standing debate on industrial policy and embeds the newer concept of the "entrepreneurial state" in this debate. The conceptual thoughts derived from the theoretical debate are applied on a policy level by focusing on two policy frameworks developed on the level of the EU, smart specialisation and Horizon 2020. Next, the article introduces three case studies from the EU's neighbourhood on a conceptual level by characterising the economic context of Israel, Tunisia and North Macedonia. In each case, major trends in economic policy and opportunities for applying policies developed in the EU in this neighbourhood (or in the case of North Macedonia, enlargement) countries are discussed. The article concludes by drawing stylised conclusions for designing and implementing industrial policies in EU enlargement and neighbourhood countries, highlights problems to be expected when industrial policy design and implementation are to be based on policy experimentation, and pays particular attention to implementation problems and needs for further research.

\section{Old and New Industrial Policies, Self-Discovery, and the Entrepreneurial State}

Many definitions of industrial policy have been proposed (e.g., Aiginger 2007, pp. 319-20; Benner 2012b, p. 76; Brösse 1999, p. 1; Conrad 1987, pp. 4-5; Landesmann 2015, pp. 133-35; Meyer-Stamer 2009, pp. 10-12; Seitz 2000, pp. 32-34; Von Einem 1991, pp. 13-15). Without going into the details of this debate, for the purposes of the present article industrial policy is understood as any set of policies that aims to affect structural change in a targeted (i.e., not exclusively horizontal) way (Benner 2012b, pp. 70-84; Landesmann 2015, pp. 133-35).

Industrial policy is the subject of a long-standing debate. While in former times, policymakers seemed to have been pragmatic when it comes to interventionist policies to drive industrialisation, as is evident in former centuries' mercantilist policies or Muhammad Ali's state-led industrialisation drive in Egypt during the 19th century, the shortcomings of protectionism, import-substituting industrialisation, "picking winners" and "national champions" led to a debate on the usefulness and efficiency of industrial policy that goes on until today (Landesmann 2015; Rodrik 2009; Waterbury 1999). However, the dominant assessment of whether industrial policy should be used at all, how useful it can possibly be, how to design it, and how to implement is has changed. The present section provides a brief overview of this debate and focuses on a newer argument calls for an "entrepreneurial state" (Mazzucato 2011, 2013) to get or stay involved in driving structural change by stimulating innovation.

\subsection{The Debate on Industrial Policy}

Industrial policies, consisting of targeted, selective, and distinctly non-horizontal policies to support particular firms, industries, or technologies, were a major tool in the toolbox of policymakers notably in the decades of World War II, both in industrialised countries and in industrialising countries (Landesmann 2015; Rodrik 2009; Waterbury 1999). After the wave of industrial policy that occurred between the 1950s and 1970s, industrial policy lost its appeal in the wake of the growing dominance of neoclassical theories, monetarism, and laissez-faire policies that came to be implemented during the 1980s notably in the United States and the United Kingdom but more or less affected other industrialised countries too (Page 2015, p. 153). The critique of traditional industrial policies referred to failures in picking winners, possible crowding out of private investment and information asymmetries (Landesmann 2015; Mazzucato 2015) as well as implementation problems such as "collusive practices between political and economic power, heavy bureaucracy, and lack of accountability and entrepreneurship" (Pianta 2015, p. 142). In the context of these tendencies, the dominant theoretical and political discourse came to favour horizontal free-market policies over targeted, selective interventions known from traditional industrial policies (Pianta 2015, pp. 139-40). 
However, in the course of the 1990s the tide changed again. A new generation of industrial policy approaches emerged from concepts such as (Porter 1990) work on industrial clusters. Drawing on a microeconomic perspective on the behaviour of interrelated industries on competitive markets, (Porter 1990) offered an approach to combine targeted policy interventions with free-market competition. Porter's work drew wide attention in the policymaker communities of most countries and sparked the wave of cluster policies that became popular during the late 1990s and early 2000s, although policies implemented usually took a much narrower perspective than that originally suggested by Porter (Benner 2012a, 2012b).

At the same time, the previously dominant neoclassical consensus was shattered by the experiences made by the East Asian newly industrialised economies (NIEs) and, later, China. This "East Asian miracle" (World Bank 1993) was not easily explained by conventional wisdom. Instead of relying first and foremost on laissez-faire policies, economic policy of these countries since the 1960s employed a comprehensive mix of horizontal and targeted policies. These policies included a degree of protectionism and import substitution that was only gradually, selectively and strategically substituted by international trade and (in some instances) investment openness. Targeted interventions on the level of firms, technologies and industries played a significant role in the NIEs' policies but were often coupled with incentives for rivalry and competition. However, the debate on the conclusions to be drawn from East Asian NIEs and their role model, Japan, was somehow inhibited by the coincidence that in the early 1990s, Japan entered a period of weak economic growth, and later by the 1997-1998 East Asian financial crisis² (Chen et al. 2001; Chiu and Lui 2001; Chu et al. 2001; Kang 2001; Wong 2001; Wong and Ng 2001; World Bank 1993).

In addition, the 1990s were the time when the discourse on the knowledge-based economy gained in popularity. In European countries, the political discourse subscribed to the argument that as other countries offered cost advantages in the assembly of manufactured goods, safeguarding employment in high-cost European economies required them to raise their productivity through innovation as well as research and development ( $\mathrm{R}$ and $\mathrm{D})$. The publication of the first edition of the "Oslo Manual" on measuring tools for evidence-based innovation policymaking in 1992 and its influential second edition from 1997 (Organisation for Economic Co-operation and Development and European Commission, and Eurostat 1997) demonstrate the growing interest in innovation policy at the time. The result was that targeted policy interventions to increase the dynamic efficiency of economies (Pianta 2015, p. 140) had become fashionable under the term "innovation policy" while basically constituting industrial policy.

Towards the end of the first decade of the 21st century, the global financial crisis and resulting recession seem to have contributed to the renewed interest in industrial policy, for two major reasons. Firstly, the financial crisis demonstrated the risks associated with "too much" market liberalisation and the volatility of the financial services industry (Page 2015, p. 153). Secondly, the slow recovery of European industry after the recession made policymakers aware that without targeted interventions to promote the emergence and growth of competitive industries, economic catching-up would be hard to achieve, notably for Southern European economies (Pianta 2015).

On the EU level, the ambitious "Europe 2020" strategy (European Commission 2010c) took up the newer trends in industrial policy and sparked a new debate on how industrial policy on the EU level should be designed (e.g., Mazzucato 2015; Page 2015; Pianta 2015). Under the umbrella of Europe 2020, the European Commission kicked off a number of "flagship initiatives". Those that are most closely linked to industrial policy are the digital agenda (European Commission 2010a), the integrated industrial policy summarising the EU's menu of economic policies (European Commission 2010b), and the innovation union (European Commission 2010d). In 2017, the Commission published its new industrial policy strategy, a policy document summarising several policy areas including innovation policy, digitalization, and the green economy (European Commission 2017). These initiatives

2 I am grateful to Dimitrios Kyriakou for making me aware of this point. 
demonstrate the resurgence of the term "industrial policy". On a deeper level, they demonstrate the new, more comprehensive and systemic understanding of industrial policy that focuses on innovation and dynamic efficiency, that seeks consistency and complementarity with competition on markets, and that draws on a policy vision very different from the one prevalent in traditional industrial policies.

Newer industrial policies tend to understand the role of government as that of a catalytic enabler and facilitator (e.g., Mazzucato 2015, p. 125) instead of a steering authority, an understanding that underscored traditional industrial policies with their focus on protectionism and picking winners that ascribed governments the prophetic role of forecasting the eventual success of firms, industries or markets. Instead of picking winners in a hierarchical, top-down way, newer industrial policies often drew on the idea of "self-discovery" (Hausmann and Rodrik 2003) to be organised jointly between the public and private sectors (Rodrik 2009, pp. 19-21). As an essentially experimental process, self-discovery implies a certain risk of failure. Since self-discovery "is inherently uncertain, many promoted enterprises will necessarily fail" (Rodrik 2009, p. 22). This experimental nature is at the core of newer industrial policies that seek consistence with the inherently uncertain and evolutionary dynamics of competitive markets (Mazzucato 2011, pp. 133-34). Industrial policy, then, has the task "to let the losers go" (Rodrik 2009, p. 22) instead of trying to find the eventual winners. This implies that policymakers adopt a probabilistic vision of industrial policy instead of the deterministic one inherent in old industrial policies including infant-industry protection and picking winners. Since competitive markets and emerging technologies may develop in unforeseen ways, industrial policy cannot predict or prescribe the course of development, but it can nurture experimentation and facilitate dynamism. Rather than protectionism, facilitating dynamism includes encouraging competition because "market discipline is helpful in so far as it weeds out the poor performers and rewards the high performers within particular populations of firms" (Cimoli et al. 2015, p. 128).

\subsection{The "Entrepreneurial State" and Its Activist Innovation Policies}

While in a neoclassical perspective governmental intervention in markets, and, thus, industrial policy, is justified by market failures in terms of static efficiency, (Mazzucato 2015) argues that to promote economic development through innovation, governments have to create markets that do not yet exist. According to (Mazzucato 2015, p. 125), industrial policy driving economic development through entrepreneurial investments in innovation has to put "an emphasis not on fixing market failures or minimising government failures but on maximising the transformative impact of policy that can shape and create markets." Instead of juxtaposing market failure and government failure, the evolutionary and complex nature of innovation requires governments to promote "mission-oriented" (Mazzucato 2015, p. 122) research and innovation, and for this end to experiment and to learn from eventual failures. In contrast to traditional industrial policies, government's role "is not about prescribing specific technologies but providing directions of change around which bottom-up solutions can then experiment" (Mazzucato 2015, p. 125). While the image of government directing the process is probably too strong and the arguments for the alleged necessity of pre-defined missions seem rather weak, ${ }^{3}$ in essence of the idea of an entrepreneurial state implies applying industrial policies that combine micro-level entrepreneurial dynamics (Benner 2014) with targeted policy interventions, and, thus, within a complex system of innovation and entrepreneurship in competitive markets (Mazzucato 2015, pp. 121-25).

Industrial policy being entrepreneurial in the sense (Mazzucato 2013, 2015) suggests is, therefore, an example from the shift industrial policy took from determinism to probabilism, as was described in the previous sub-section. Instead of expecting to recognise and pick winners on the outset, this

3 The main argument for why mission orientation is not a necessity for entrepreneurial industrial policies is that if experimentation is key to these policies, why should the scope for experimentation be limited to the borders set by pre-defined missions? 
new vision of industrial policy focuses on governments to enable experimentation by setting up a portfolio of entrepreneurial investments (defined broadly and including $\mathrm{R}$ and $\mathrm{D}$, education and training, entrepreneurship, and other innovation-related actions) similar to the business model of a venture capital fund, nurturing these investments, and expecting that some of them will fail while others might eventually drive economic development (Mazzucato 2015, pp. 123-24). ${ }^{4}$

The inherent uncertainty in investing in a portfolio of technologies and ventures and the related risk of partial failure is not a simple downside of newer industrial policies but their justification. According to (Mazzucato 2011, 2013), the main task of the entrepreneurial state in driving structural change by investing in research and innovation is to invest under conditions not yet amenable to private investment because uncertainty is still too high. Under these conditions, government has to set off the innovation and structural-change process, bear the risk of (partial) failure, and thereby reduce uncertainty to levels that enable subsequent private investment. By doing so, government critically contributes to self-discovery. Experimentation is an essential feature of the first stages of innovation, notably in general-purpose technologies, and may lead to unforeseen and serendipitous outcomes on the positive side, as well as to failures to achieve planned outcomes, but all of these possible results reduce uncertainty and, thus, make private investment (notably in applied research and development as well as subsequent commercialisation of $R$ and $D$ results) in the markets shaped or even created by government more likely (Mazzucato 2011, pp. 131-35).

While the idea of the entrepreneurial state is somewhat fuzzy and sometimes narrowed down to the mission orientation ascribed to it, the fundamental rationale behind it is very much in line with newer industrial policies. The common thrust of these newer approaches is that government is to play a facilitating role for market-based industrial development and has to step in to support the knowledge-based development of an economy by funding research, encouraging innovation, and stimulating experimentation and entrepreneurship. Summing up the ideas presented so far, newer industrial policies following the basic rationale of an entrepreneurial state feature the following key aspects:

- A facilitating role for government: instead of attempting to steer innovation dynamics, government plays a catalytic role to support innovative dynamics in the complex socio-economic workings of an innovation system;

- A portfolio approach: instead of picking winners, government invests in activities driving structural change (e.g., R and D, education and training, entrepreneurship) on a broad level and in a diversified way;

- An approach favourable to experimentation: related to the risk-taking attitude of the entrepreneurial state, policies encourage experimentation in the economy, and policymakers engage in policy experimentation and learning;

- A risk-taking attitude: instead of pursuing a deterministic policy vision, policymakers accept that only a fraction of investments and policies in their industrial-policy portfolio will eventually be successful, and see failure as a chance for learning;

- A focus on self-discovery: instead of assuming an omniscient government, new industrial policies feature some mechanism for self-discovery by public and private agents; and

- A mission-oriented approach: it is not clear why defining missions should strictly be necessary for entrepreneurial industrial policies, but it is possible that doing so may help in selecting portfolios. However, missions should not be defined too narrowly because too narrow missions may limit the scope of self-discovery and experimentation.

4 The question of how these investments when commercialised, e.g., by eventually successful companies, pay off for government and society is discussed by (Mazzucato 2011, pp. 138-39; 2013, 2015, pp. 124-25). While this question is socially highly relevant and politically worth considering, it is beyond the scope of industrial policy design and implementation and will not be further pursued here. 
These aspects will guide the further analysis of policies in the remainder of this article, both on the EU level and in enlargement and neighbourhood countries.

\subsection{Policies for the "Entrepreneurial State": The European Experience}

The EU's recent industrial policy strategy summarises the policies, programmes and initiatives relevant for industrial policy. While the summary is extensive and relates to a wide range of policy areas, such as environmental policy, the single market, regulation and many others, those programmes mentioned that directly affect structural change include the following ones (European Commission 2017):

- The European Structural and Investment Funds (ESIF) under the EU's cohesion policy (European Regional Development Fund, European Social Fund, Cohesion Fund) and under the Common Agricultural Policy (European Agricultural Fund for Rural Development, European Maritime and Fisheries Fund);

- The smart specialisation approach anchored in the framework of cohesion policy as an ex-ante conditionality for access to innovation-related lines of ESIF co-funding, and EU support actions such as the Commission's Smart Specialisation Platform and its thematic platforms, such as the one on industrial modernisation;

- The current R and I framework programme Horizon 2020;

- The SME (small and medium-sized enterprises) support programme COSME that includes, for instance, entrepreneurship and incubation support;

- Further support vehicles for innovation, industrialisation and entrepreneurship support, such as the European Fund for Strategic Investments, the Cultural and Creative Sector Guarantee Facility Fund, the European Observatory for Clusters and Industrial Change, or the Connecting Europe Facility.

This brief overview demonstrates the wide array of EU-level actions that qualify as industrial policy by seeking to enhance the European economy's dynamic efficiency through structural change in a targeted, non-horizontal way. Two of these policy frameworks, Horizon 2020 and smart specialisation (and its implementation in the framework of the cohesion policy and ESIF co-funding), will be addressed in more detail here. Given their quantitative importance, their ambition in driving structural change, and their outreach to the EU's neighbourhood and beyond, Horizon 2020 and smart specialisation/cohesion policy are probably the most salient pillars of the EU's current industrial policy.

The smart specialisation approach grew out of the debate on newer industrial policies and originated in the EU's "Knowledge for Growth" Expert Group, although it shared basic characteristics other concepts, such as platform policies (Asheim et al. 2011) and can, thus, be seen as one particular strand of a broader discourse. The original idea was to focus $\mathrm{R}$ and $\mathrm{D}$ investments in the EU to make Europe a more competitive location for $\mathrm{R}$ and $\mathrm{D}$ internationally, and to do so by developing regional centres of excellence (Foray and Ark 2007). Later, when the concept was further refined by the expert group and the European Commission's Joint Research Centre, the idea of smart specialisation was sharpened, and it achieved an explicitly spatial dimension. ${ }^{5}$ The main spatial idea was that leader regions focus their $\mathrm{R}$ and $\mathrm{D}$ investment on the development of general-purpose technologies while follower regions should focus on applying these technologies. To do so, agents on the regional level are supposed to identify capabilities, strengths and opportunities available in the region in a collective process of self-discovery (Hausmann and Rodrik 2003) called entrepreneurial process of discovery (Foray et al. 2009; McCann and Ortega-Argilés 2015).

Since its emergence, the concept of smart specialisation has been refined and reviewed both on the policy and academic levels (e.g., Foray 2017; Foray et al. 2012; McCann and Ortega-Argilés 2015;

5 I am grateful to Dimitrios Kyriakou for making me aware of this point. 
Radosevic 2017a, 2017b). At the same time, a wide spectrum of experimentation with policy design and implementation according to the smart specialisation process has ensued across EU regions. To access innovation-related ESIF co-funding during the 2014 to 2020 period, EU member states had to develop policy frameworks for smart specialisation. This ex ante conditionality led to the design of Research and Innovation Strategies for Smart Specialisation (RIS3) in regions across Europe (Radosevic 2017a, p. 20). Given that through the conditionality smart specialisation was made a cornerstone of current cohesion policy, its relevance for regional development is obvious. At the same time, with its targeted and non-horizontal orientation and its focus on driving structural change and on enhancing dynamic efficiency, smart specialisation qualifies as a new industrial policy. Indeed, Radosevic (Radosevic 2017a, 2017b) understands smart specialisation as the EU's current industrial policy. In any case, within the broader view of the Commission on industrial policy (European Commission 2017) the smart specialisation approach is one of the most relevant pillars, underscored by the high quantitative relevance of ESIF co-funding across the EU.

Notwithstanding the role of RIS3 in aligning ESIF co-funding more closely with higher-level policy objectives as defined primarily in the Europe 2020 strategy, it appears that the main benefits of the smart specialisation approach notably in lagging regions in Southern and Eastern Europe refer to policy learning and further governance-related and institutional aspects of industrial policymaking. By cooperating during the collective entrepreneurial discovery process (EDP), public and private agents can build mutual trust, reputation and credibility, and policymakers and other public-sector agents develop a better understanding for private-sector views and economic patterns. At the same time, cross-sectoral policymaking can improve during the process because of different ministries and agencies working together. In this regard, it seems as if the procedural side of smart specialisation reflects the basic tenets of newer industrial policies because the approach appears to support the institutional preconditions to learning, experimentation, and collective self-discovery (Benner 2018; Kroll 2015; Trippl et al. 2018).

The other major policy framework highly relevant for the EU's industrial policy is the current $R$ and I framework programme called Horizon 2020. The programme promotes both scientific R and D and applied innovation and consists of three priorities: (i) excellent science; (ii) industrial leadership; and (iii) societal challenges (Art. 5, EU Regulation No. 1291/2013). The first priority includes funding for research projects awarded by the European Research Council, support for collaborative research in emerging technologies, and the promotion of researcher mobility and research infrastructure. The second priority on industrial leadership focuses on promoting innovation notably in SMEs and in a defined set of enabling technologies. The third priority refers to a list of defined societal challenges and support multi-disciplinary research (Annex 1, EU Regulation No. 1291/2013).

The next framework programme for the period from 2021 to 2027 is meant to focus on the definition of ambitious and multi-disciplinary $\mathrm{R}$ and I missions, according to the Commission's proposal (European Commission 2018b). The focus on missions defined more precisely than the societal challenges that are part of Horizon 2020 is a recommendation derived from (Mazzucato 2011, 2013, 2015) ideas on the entrepreneurial state. As (Mazzucato 2018) argues in her recommendations for the European Commission, defining broad societal missions can lead to agents from different disciplines to work together and, thus, mobilise dynamism for structural change. At the same time, mission orientation is supposed to provide policy with a focus on achieving defined societal impacts but should be coupled with government investments in $\mathrm{R}$ and I portfolios and the encouragement of experimentation (Mazzucato 2018).

Comparing the two policy frameworks introduced suggests that both follow differing but complementary rationales. While the smart specialisation approach under the umbrella of cohesion policy pursues a territorial logic that focuses on endogenous development of every region, Horizon 2020 pursues a spatially blind logic striving for excellence. However, both major pillars of EU industrial policy reflect the primary tendencies of newer industrial policies by putting an emphasis on experimentation, self-discovery and public entrepreneurial investments to facilitate subsequent private 
investment by reducing uncertainty. While Horizon 2020 is designed to promote excellent research and prepare its commercialisation through innovation, the smart specialisation approach is supposed to enable regional policymakers and private-sector agents to benefit from these innovative impulses by developing their context-specific strategies and using ESIF spending accordingly. The procedural impact of the smart specialisation approach in improving self-discovery and governance capabilities on the regional level (Benner 2018; Kroll 2015; Trippl et al. 2018) can improve the preconditions for this complementarity to unfold. The mission orientation foreseen for the next framework programme called "Horizon Europe" (European Commission 2018b) could underscore the EU's ambition to act according to the rationale of the entrepreneurial state and, thus, if successful, strengthen dynamic opportunities for regional EDPs and RIS3 to seize.

In terms of the major aspects of new industrial policies introduced in the previous sub-section, the two main frameworks of EU industrial policy presented above exhibit a number of aspects of entrepreneurial industrial policies. The smart specialisation approach including RIS3 implementation through a portfolio of ESIF-funded projects centres on facilitation and self-discovery. Given the need for regions or nations to come up with their own smart specialisation frameworks and strategies and the concomitant EDP, the smart specialisation approach encourages experimentation on the policy level but the degree to which it favours experimentation by agents in regional economies depends on the case at hand. The competitive logic of Horizon 2020 combines top-down support with bottom-up dynamics in $\mathrm{R}$ and $\mathrm{I}$, and the various sub-programmes suggest a portfolio approach through the $\mathrm{R}$ and $\mathrm{D}$ projects funded under different lines of funding. Horizon 2020 implies a considerable degree of risk-taking because the outcomes of ambitious $\mathrm{R}$ and $\mathrm{D}$ are uncertain. In the future, Horizon Europe will most likely strengthen the mission orientation of EU industrial policy.

From the previous discussion, it has become clear that the EU's industrial policy with smart specialisation and Horizon 2020, as its arguably most important policy frameworks, has significantly evolved during recent years. Given the strong economic interrelationships between the EU and its Southern and Eastern neighbourhood, the ambition of South East European economies to join the EU, and Europe's interest in providing countries in its neighbourhood with perspectives for economic integration and shared prosperity, it is worth considering the actual and potential relevance of these newer trends in EU industrial policy for enlargement and neighbourhood countries. In particular, how do these policy experiments and experiences fit with industrial policies pursued in enlargement and neighbourhood countries? What can enlargement and neighbourhood countries learn from current EU industrial policies? What can the EU learn from their experiences? Additionally, what possibilities for cooperation exist under current or future EU industrial policy frameworks? The next section addresses these questions by looking at three case studies.

\section{Case Studies from the EU's Neighbourhood}

Despite differing contexts, the debate on industrial policy is globalized in the sense that experiences made in some parts of the world inform the academic discourse and policy considerations in other parts. This is why the case of the East Asian NIEs has been so crucial in rebalancing the common assessment on industrial policy since the early 1990s, just as did the case of import-substituting industrialisation in Latin America in earlier decades (Richards and Waterbury 2008). Currently, the EU's use of the smart specialisation approach is gaining international attention, as is seen countries in other parts of the world registering in the European Commission's Smart Specialisation Platform. ${ }^{6}$ Given the economic and spatial proximity, it seems plausible that mutual learning from experiments and experiences in industrial policy is most useful between the EU and its immediate enlargement area and neighbourhood.

6 I am grateful to Monika Matusiak for drawing my attention to this point. 
Neighbouring countries are intertwined with the EU in a number of ways. Western Balkan countries are either candidates for EU enlargement or potentials candidates. Similarly, Turkey is a candidate country. As such, these countries benefit from EU assistance through funding from the Instrument for Pre-accession Assistance (IPA). In the Eastern and Southern neighbourhood, economic cooperation between countries and the EU is governed by association agreements and supported through a specific funding vehicle, the European Neighbourhood Instrument (ENI), under the umbrella of the European Neighbourhood Policy (ENP). These policy frameworks demonstrate the importance of close economic cooperation and partial integration between the EU and its Mediterranean neighbours. While these policy frameworks cover a wide range of policy areas, the present section focuses on possibilities of cooperation between the EU and neighbouring countries in industrial policy under the policy frameworks introduced above, possibilities for mutual policy learning, and possible complementarities with neighbouring countries' home-grown industrial policies.

\subsection{Methods and Approach}

The selection of the three case studies presented was guided by the consideration that mutual policy learning can be particularly relevant between the EU and its enlargement and neighbourhood countries due to wide-ranging economic integration, spatial proximity, participation in some of the EU's policy frameworks, and more or less far-reaching alignment with EU law or standards under the framework of either eventual EU accession (in the case of enlargement countries) or association agreements (in the case of neighbourhood countries).

Within this group of countries, Israel is the singular case of an industrialised country outside of the EU but economically and spatially close to it. ${ }^{7}$ Among middle-income countries in the Southern Mediterranean, Tunisia is one of the most dependent on trade with the EU and a frontrunner in economic alignment under the umbrella of its association agreement with the EU. North Macedonia stands as an exemplary case for countries aspiring to join the EU, together with other candidates or potential candidates in the Western Balkans as well as Turkey.

The case studies presented draw mainly on desk research through an analysis of scholarly literature and policy documents. In the case of Israel, scholarly literature is widely available and the author could draw on earlier studies he worked on. In the case of Tunisia, in addition to available scholarly literature, the author was able to draw on insights from semi-standardised telephone or Skype interviews undertaken for an earlier research project (Benner 2019). In the case of North Macedonia, the stock of available literature is limited but the author benefited from his context knowledge due to his work in the Smart Specialisation Platform's team assisting enlargement countries. The case studies are meant to highlight some thoughts on mutual learning on industrial policies in a stylised way but do not claim to be comprehensive policy evaluations.

\subsection{Israel}

Israel is part of the EU's Southern neighbourhood and, as such, benefits from the ENP. EU-Israel cooperation is governed by a number of agreements between the EU and Israel, the most important being the association agreement (AA) signed in 1995 and in force since 2000. Cooperation is older though, going back to the cooperation agreement dating from 1975. Economically, the major provisions of the AA refer to free trade, but other subjects covered include scientific cooperation, as well as industrial cooperation, including the objectives of contributing to industrial diversification of the Israeli economy, enhancing cooperation between SMEs from both sides, and stimulating innovation (Delegation of the European Union to Israel 2016).

7 The United Kingdom may become the second county to fit these criteria upon its eventual withdrawal from the EU. EFTA countries or Switzerland do not fall into the same category because of their far-reaching alignment with the EU acquis. 
Apart from the AA, sectoral agreements deepen mutual cooperation between the EU and Israel, and some of them are relevant for industrial policy and, more generally, for structural change. For example, an agreement liberalising trade in agricultural products was signed in 2009 and entered into force in 2010. Another agreement associates Israel to Horizon 2020 for the period from 2014 to 2020. This important agreement grants Israeli entities from the academic and private sectors full access to Horizon 2020 on the same terms as those enjoyed by EU entities (Delegation of the European Union to Israel 2016; European Commission 2019; Garcia-Torres 2016, p. 32).

$\mathrm{R}$ and $\mathrm{I}$ is an important area for cooperation between the EU and Israel because Israel is well above the EU average on a number of innovation-related indicators. For instance, Israel's gross expenditure on $R$ and D (GERD) in 2014 stood at 4.11 percent of GDP, more than twice the EU average of 2.03 percent. The country's vibrant entrepreneurial and high-technology scene (Avnimelech and Teubal 2006; Breznitz and Ornston 2013; Trajtenberg 2001; Wonglimpiyarat 2016) has attracted international attention. When compared to previous $\mathrm{R}$ and $\mathrm{D}$ framework programmes, the participation of entities from Israel in Horizon 2020 seems to increase (Garcia-Torres 2016, pp. 11, 26, 39; Wonglimpiyarat 2016, p. 21).

Apart from Israel's participation in Horizon 2020, the country experimented with its own set of industrial policies, notably when it comes to stimulating innovation (Trajtenberg 2002). The government reoriented its industrial policy at the beginning of the 1990s due to an industrial crisis at the end of the 1980, the urgent need to create employment for immigrants from the former Soviet Union, and the perceived lack of effectiveness of the previous innovation policies with their $\mathrm{R}$ and $\mathrm{D}$ grants for the private sector. A number of initiatives were kicked off under the new wave of industrial policies in Israel since the early 1990 by the Office of the Chief Scientist within the Ministry of Economy (today: Israel Innovation Authority). A major milestone of Israel's new industrial policy was the Yozma programme that ran from 1993 to 1997 and somewhat built on the failed Inbal investment insurance programme launched in 1992. The programme was designed to catalyse investment in high-technology start-ups by establishing venture capital funds both with government and private money. Under this construction, government funds leveraged private investment and facilitated the emergence of a venture capital industry. Ten funds were managed privately but one fund was fully government-owned to kick-start investments at the beginning. Under the Yozma programme, roughly 200 start-ups benefited from investment (Avnimelech and Teubal 2006; Wonglimpiyarat 2016; Trajtenberg 2002).

Yozma offers a particularly illustrative example of how the entrepreneurial state played out in Israel. By investing public money in early-stage high-technology start-ups, government stepped in when uncertainty was greatest. At the same time, government funds were leveraged by private funds, motivated by the upside incentives set by private investors being granted the option to buy the government share in the fund after five years. The wider catalytic effects of Yozma included the emergence of a local venture capital industry even beyond the funds set up under the programme. In this sense, instead of the crowding-out of private investment traditional industrial policies are criticised for (Mazzucato 2015), the Yozma programme had a crowding-in effect (Wonglimpiyarat 2016, pp. 18, 26). Further, Yozma is an example for self-discovery because it led to collective learning in the public and private sector alike. However, the uncertainty inherent to early-stage investment and policy experimentation could have played out differently, as the failure of the Inbal programme demonstrates. However, given that both programmes started almost simultaneously (with only one year in between), it seems that the differing designs of both programmes made it more likely that at least one of them would succeed. Thus, the combination of both programmes is not only an example for policy experimentation with policy instruments complementary to competitive markets and catalytic effects but also for a policy portfolio approach (Avnimelech and Teubal 2006, pp. 1488-91; Wonglimpiyarat 2016, pp. 23-24).

Other policies implemented by the Office of the Chief Scientist (OCS) during the 1990s and early 2000s followed the same entrepreneurial-state logic as Yozma. Programmes started since the beginning of the 1990s include the Magnet programme for collaborative generic research, the technological 
incubators programme that is said to support the creation of about 70-80 new businesses annually, the Tnufa programme for start-up assistance in the pre-seed phase, the Nofar programme for applied biotechnology $\mathrm{R}$ and $\mathrm{D}$, and the Heznek seed fund that matches private investments with public funds (Breznitz and Ornston 2013, p. 1235; Trajtenberg 2002; Wonglimpiyarat 2016, pp. 24-26). These programmes share the basic functions of the Yozma programme with the government stepping in during the early stages of the innovation and entrepreneurship process, contributing to collective self-discovery, reducing uncertainty and thereby gradually leveraging and crowding in private investment, and pursuing a portfolio approach while accepting the risk involved. The programmes were the outcomes of a long-term policy experimentation process within OCS encouraged by the independence of the agency and its formerly peripheral status that assured a certain degree of freedom from political interference (Breznitz and Ornston 2013, pp. 1231-38).

While there is no policy framework for smart specialisation in Israel, (Garcia-Torres 2016, pp. 21-22) argues that some policies pursued on the national and local levels, such as the designation of regional $\mathrm{R}$ and $\mathrm{D}$ centres and the emerging cybersecurity cluster in the Southern city of Be'er Sheva follow a smart specialisation logic. Further, in their analysis of Haifa's local economy, (Benner et al. 2016) identify complementarities between industries rooted in underlying capabilities in $R$ and $D$, suggesting that regions in Israel could indeed benefit from developing their own RIS3.

Two conclusions can be drawn from the Israeli case. First, the economic cooperation between the EU and Israel extends notably to the country's active participation in Horizon 2020 and is quite compatible with Israel's home-grown industrial policies to promote innovation. Second, there is considerable room for mutual policy learning on how to design and implement effective, new-generation industrial policies. On the one hand, the EU and its member states can benefit from the Israeli experience in entrepreneurial-state policies carried out by OCS with their risk-taking attitude and portfolio approach. While Horizon 2020 and, most likely, Horizon Europe pursue a similarly entrepreneurial logic in promoting $\mathrm{R}$ and $\mathrm{I}$, extending this logic to other parts of industrial policies, such as SME support could be worth considering and inspired by the Israeli experiences. On the other hand, the entrepreneurial-state industrial policies pursued by OCS are spatially blind (with the partial exception of the technological incubators programme). Given innovative and dynamic regional innovation ecosystems not only in the centre of the country (notably the Tel Aviv agglomeration) but also in its more peripheral areas, such as Haifa, Nazareth or Be'er Sheva, drawing on self-discovery, portfolio policies and policy risk-taking regionally under the smart specialisation approach could well complement the national-level innovation and industrial policies.

\subsection{Tunisia}

As part of the EU's Southern neighbourhood, Tunisia cooperated politically and economically with the EU within the framework of the ENP. The country signed an association agreement (AA) with the EU in 1995 that included free trade (M'Henni and Deniozos 2013, p. 3; Murphy 2006, p. 526). Further, the country is associated to the EU's current R and D framework programme Horizon 2020 which enables Tunisian entities to participate in the programme on the same terms as entities from the EU (European Commission 2019). In general, the Tunisian economy exhibits a high degree of integration with the EU economy, as is evident from the dependence of Tunisia's exports and foreign direct investment on EU countries (Achy 2010, p. 11; Erdle 2011, p. 40; World Bank 2014, p. 311).

To prepare Tunisian industry for the implementation of the AA and related free-trade area, in 1995 the Tunisian government started an ambitious upgrading programme called Programme mise à niveau (PMN). The rationale was that opening the Tunisian market for competition from the EU would put pressure on Tunisian industry, and to cope with that pressure as well as to be able to seize export opportunities after the opening of EU markets, Tunisian firms would have to upgrade their competitiveness. The model was the PEDIP programme designed to upgrade Portugal's industry in the wake of EU accession, beginning in 1988. The PMN offered both technical and financial assistance to firm upgrading, based on a diagnosis undertaken by firms according to problems defined by 
themselves. The programme was supported by international donors including the EU but steered by the Tunisian government with participation of the private and financial sectors, the UTICA trade association federation, and the UGTT trade union federation. The PMN is generally considered successful, despite some criticism including towards the sectorally and spatially uneven distribution of beneficiary firms (Benner 2015, pp. 69-70; Cammett 2007; Erdle 2011, pp. 31-35; Ghali and Rezgui 2015, p. 54; Hazboun 2008, pp. 74-75; Murphy 2006; Rivlin 2009, pp. 281-82).

While R and I indicators, such as GERD for Tunisia appear rather low in international comparison, taking a comprehensive look at the country's relative industrial diversification as well as its research, innovation and education outcomes place the country among the best performers in the Middle East and North Africa. Indeed, it seems that as an economy in an intermediate state of industrialisation based on manufacturing industries, such as mechanical and electrical engineering, textiles as well as tourism, the country is on its way towards becoming a more knowledge-based economy, as is evident in the rising technological sophistication of its efforts. Indeed, (Richards and Waterbury 2008, p. 68) classify Tunisia, together with Jordan and Israel, as one of the resource-poor "watchmaker" economies that have to focus on skills-intensive manufacturing to industrialise (Diop and Ghali 2012; Ghali and Rezgui 2015; Hazboun 2008; M’Henni and Deniozos 2013; Richards and Waterbury 2008).

The pôles de compétitivité programme is arguably the most prominent initiative to support Tunisia's move towards becoming a more knowledge-based economy during the past two decades. This programme combined the rationale of innovation-driven innovation policy with a spatial perspective inspired by the cluster debate. A pôle de compétitivité typically consists of a technology park hosting anchor companies and SMEs, higher education and research institutes, and an incubator. Depending on the industry targeted, the pôle might further include an industrial zone. To stimulate innovative networking between companies and other agents resident in the technology park or industrial zone and their wider regional or national ecosystem, formalised networks often called "clusters" were established. The pole de compétitivité programme was inspired by the success of the Elgazala technology park for information and communication technologies set up from 1999 in the Tunis agglomeration that managed to attract major multinational companies as anchor tenants. Newer pôles were set up in other parts of the Tunis agglomeration (pharmaceuticals, biotechnology), in other industrial centres of the country, such as Monastir (textiles and garments), Sousse (electronics and mechatronics) or Sfax (information and communication technologies), and in more peripheral regions, such as Bizerte (agrifood) while further ones are planned for lagging regions in the interior of the country (Aubert et al. 2013, pp. 99-101; Benner forthcoming; Erdle 2011; Ghali and Rezgui 2015; Lehmann and Benner 2015; M’Henni et al. 2013; Rodríguez-Pose and Hardy 2014, pp. 56-57).

Considering the strong spatial aspect of Tunisia's innovation policy, it seems worth considering the smart specialisation approach for Tunisia (Benner forthcoming). Indeed, Tunisia is currently preparing pilot projects on smart specialisation in selected regions with support from the European Commission's Smart Specialisation Platform. Given the traditional top-down orientation of Tunisia's industrial and innovation policy evident in the definition of the pôles de compétitivité (Benner 2015, pp. 204-5), introducing the smart specialisation approach and applying it to Tunisia could contribute to policy experimentation and achieve a more entrepreneurial orientation of industrial policy. While the PMN was a major step in Tunisian industrial policy, its transformative vision was limited and reactive because of the foreseen competitive pressures upon free trade with the EU. Anchoring collective self-discovery and a technologically more transformative vision could be achieved on the regional level by implementing some form of EDP under the smart specialisation approach.

Further, the prospect of a Deep and Comprehensive Free Trade Area (DCFTA) with the EU extending and enhancing free trade (European Commission 2018c), suggests that a further upgrading effort will be necessary that could be similar to the PMN. It could be worthwhile to consider defining the priorities of such an eventual new upgrading programme according to regional RIS3, thereby drawing on collective public-private self-discovery and making a portfolio approach of industrial policy more likely. 


\subsection{North Macedonia}

As a candidate for EU membership, North Macedonia benefits from IPA assistance. Furthermore, since the country is associated with Horizon 2020, entities from North Macedonia can participate in the R and I framework programme on the same terms as entities from EU member states (European Commission 2019). However, the success rate of North Macedonian participation in Horizon 2020 is rather low at 10 percent while participation is increasing (European Commission 2018a, p. 77; Matusiak and Kleibrink 2018, p. 23). Despite North Macedonia's status as a candidate country, accession negotiations were not started yet and consequently, no negotiating chapters have been opened so far. Upon the eventual start of accession negotiations, alignment of the country's policies with the EU acquis communautaire will lead to the adoption of the EU's policy frameworks related to industrial policy.

So far, North Macedonia has, in recent years, experimented with newer approaches of industrial policy. These efforts included the set-up in 2013 of the Fund for Innovation and Technological Development that provides funding of $\mathrm{R}$ and $\mathrm{D}$, as well as assistance for SMEs and start-ups (Josimovski 2014). In particular, the fund allocates grants to start-up and spin-off firms, loans and grants for commercialising innovations, technology transfer grants, and technical assistance including acceleration services (OECD 2018, p. 367). Further, the country established an innovation voucher scheme, although with a limited impact due to its weak funding (OECD 2018, p. 373). On a strategic level, the (OECD 2018, p. 352) emphasises North Macedonia's 2012 holistic innovation strategy and inter-ministerial coordination of innovation policy. However, as the relevant enlargement report (European Commission 2018a) states, industrial policy in North Macedonia suffers from a lack of coordination and funding, and grants awarded by the Innovation Fund, were absorbed slowly so far (European Commission 2018a, pp. 49, 74-77).

North Macedonia, with support from the European Commission's Smart Specialisation Platform, is currently introducing the smart specialisation approach (Matusiak and Kleibrink 2018). The EDP is supposed to lead to the design and subsequent implementation of a national-level RIS3. Similar to the case of other former Yugoslav republics and transformation economies, such as Croatia and Slovenia (Benner 2018), North Macedonia's EDP could improve institutional patterns for the design and implementation of industrial policy by establishing trust and policy credibility, and, thus, by anchoring new routines for collective, public-private self-discovery capabilities. Further, the EDP and resulting formulation of a RIS3 could further strengthen the cross-sectoral character of industrial (including innovation) policy in North Macedonia. In the case of North Macedonia, implementation of the eventual national RIS3 is not legally linked to EU funds as is the case under EU cohesion policy in member states. Thus, during the EDP it is worth considering linking national $\mathrm{R}$ and I spending and possible IPA co-funding to the priorities defined in the RIS3. Further, during the EDP the role of the innovation fund and the possible complementarity between the fund's activities and RIS3 implementation should be considered.

In general, in North Macedonia's more recent industrial policy the innovation fund exhibits a certain degree of portfolio orientation due to its various lines of competitive calls for funding of bottom-up projects. The current smart specialisation exercise can serve as an arena for further policy experimentation and is likely to contribute to the definition of economic and innovative priorities. It remains to be seen if the activities of the innovation fund will be focused on these priorities, thus following the smart specialisation approach, or complement it by encouraging experimentation horizontally. The EDP may provide an opportunity to discuss the advantages and disadvantages of either possibility. Further, the EDP could serve as an arena to discuss how to seize the opportunities arising from North Macedonia's association to Horizon 2020 or, in the future, Horizon Europe. Further, the fit between the priorities defined in the RIS3 and the missions likely to be defined under Horizon Europe could be discussed and actions planned accordingly. Together with capacity building measures for applicants, doing so could provide a possibility to increase the success rate of North Macedonian participation. Lastly, when accession negotiations begin and chapters relevant to industrial policy are 
opened, policy alignment with the EU acquis could provide further opportunities for North Macedonia that might be anticipated and prepared during the EDP.

\section{Conclusions and Policy Implications}

The case studies in the previous section served to highlight a number of aspects in the context of EU industrial policies, represented by the policy frameworks of Horizon 2020 and smart specialisation, in enlargement and neighbourhood countries.

The case of Israel provides a perspective on how the revival of industrial policy with more market-based, entrepreneurial industrial policies since the 1990s played out in an industrialised economy economically close to the EU. Given the success of Israel's industrial policies in driving knowledge-based industrial development and their complementarity with newer frameworks of EU industrial policy, such as Horizon 2020, with its transformative ambition and the upcoming next framework programme Horizon Europe with its mission orientation, Israel and the EU could benefit from mutual policy learning. In particular, the strong portfolio approach, the risk-taking attitude, and the willingness to learn from failure are features of Israel's newer industrial policies that could prove important insights for EU industrial policy. On the other hand, given the weak spatial orientation of Israel's industrial policies, the country could benefit from applying the smart specialisation approach in peripheral, but promising, regional innovation ecosystems.

The Tunisian case is remarkable because of the revival industrial policy witnessed in the wake of EU rapprochement, above all under the PMN. Apart from this spatially blind programme, the second salient thrust of newer industrial policies in Tunisia since the 1990s is the pôles de compétitivité programme that combines two rationales, one focusing on territorial development and another one focusing on innovation. The top-down design of the programme underscored Tunisia's ambition in using industrial policy to drive structural change towards becoming a more knowledge-based economy, but leaves opportunities arising from the endogenous potential of regions and from revealing them through self-discovery aside. The smart specialisation approach whose introduction to Tunisia is currently being prepared has the potential to fill this void.

Given the foreseeable alignment of North Macedonia's policies and legal frameworks to the EU acquis during eventual accession negotiations, EU trends in industrial policy will most likely become even more relevant for the country. Even now, during the current adoption of the smart specialisation approach in North Macedonia and the upcoming EDP leading up to the formulation of a national-level RIS3, the country is likely to benefit from experiences made by spatially close EU member states such as Slovenia and Croatia (Benner 2018). ${ }^{8}$ Further, the country's innovation fund could be developed into a vehicle for implementing a portfolio-based, entrepreneurial industrial policy.

Table 1 briefly summarises stylised conclusions and policy implications that can be drawn from the case studies. However, given that the case studies can only highlight some ideas and are no substitutes for comprehensive policy evaluations, the conclusions and policy implications suggested in Table 1 should be regarded as preliminary.

8 Apart from EU member states spatially close to North Macedonia, Serbia and Montenegro are more advanced in introducing the smart specialisation approach and can similarly provide lessons and experiences for the smart specialisation process in North Macedonia. 
Table 1. Stylised conclusions and policy implications for the case studies.

\begin{tabular}{|c|c|c|}
\hline Israel & Tunisia & North Macedonia \\
\hline $\begin{array}{l}\text { Role of portfolio approach } \\
\text { and policy experimentation } \\
\text { and related self-discovery } \\
\text { (Yozma programme) } \\
\text { Importance of learning from } \\
\text { policy failure } \\
\text { (Inbal programme) } \\
\text { Importance of independent } \\
\text { and peripheral agency for } \\
\text { policy experimentation } \\
\text { Need for attention for } \\
\text { place-based policies for } \\
\text { promising peripheral } \\
\text { regional innovation systems } \\
\text { (e.g., smart specialisation in } \\
\text { Haifa and Be'er Sheva) }\end{array}$ & $\begin{array}{l}\text { Role of large-scale upgrading } \\
\text { programme (Programme mise } \\
\text { à niveau) with some degree } \\
\text { of self-discovery } \\
\text { Role of place-based policies } \\
\text { (pôles de compétitivité) but } \\
\text { strong top-down orientation } \\
\text { - } \quad \text { Need for more attention to } \\
\text { self-discovery (e.g., through } \\
\text { smart specialisation in } \\
\text { pilot regions) } \\
\text { Possible need for further } \\
\text { upgrading upon DCFTA } \\
\text { synchronised with smart } \\
\text { specialisation priorities }\end{array}$ & $\begin{array}{ll}\text { - } & \text { Experimentation in industrial } \\
\text { policy (setup of } \\
\text { Innovation Fund) } \\
\text { - } \quad \text { Initial steps towards portfolio } \\
\text { approach (various lines of } \\
\text { competitive } \\
\text { innovation funding) } \\
\text { - } \quad \text { Expected impact of EU } \\
\text { accession negotiations on } \\
\text { industrial policies } \\
\text { Introduction of smart } \\
\text { specialisation possibly } \\
\text { improving institutional } \\
\text { conditions for self-discovery } \\
\text { Need to improve } \\
\text { implementation capabilities } \\
\text { (e.g., coordination, } \\
\text { funding, take-up) }\end{array}$ \\
\hline
\end{tabular}

Source: own work.

Coming back to the main aspects of new industrial policies following the idea of the entrepreneurial state, the case studies suggest important lessons. Israel's new industrial policies can serve as examples for entrepreneurial-state policies characterized by a facilitating role for government, a portfolio approach, a strong risk-taking attitude, encouragement to both policy and economic experimentation and related policy learning, and self-discovery mechanisms. Tunisia's PMN and pôle de compétitivité programmes are less characteristic for entrepreneurial-state policies, but still played a facilitating role, and the PMN may be seen as a way of self-discovery on a large, national scale. North Macedonian industrial policy so far features the least degree of entrepreneurial-state orientation but the country's innovation fund, with its four lines of funding, could provide a vehicle for a facilitating and portfolio-based approach, and the current smart specialisation exercise is likely to introduce a routine of self-discovery.

The transformative ambition of entrepreneurial industrial policies is likely to be more complex in middle-income countries such as Tunisia or North Macedonia than in industrialised countries, such as Israel or technologically leading EU member states. However, there is no reason to assume that entrepreneurial industrial policies are not be applicable in middle-income countries. While some scientific or technological fields marked by high capital intensity and increasing returns to scale will be less accessible for middle income countries to tap into, others (such as information and communication technologies) will be more accessible and could possibly engender leading-edge innovations in middle-income countries as well as in industrialised countries. While in less accessible fields, catching up and applying technologies is probably a more appropriate goal than developing entirely new knowledge, the transformative ambition of industrial policies in middle-income countries could be higher in more accessible fields. These more accessible fields include non-technical innovation, like service innovation, such as in the tourism sector or innovation in cultural and creative industries-aspects often neglected in the entrepreneurial-state discourse that seems to assume innovation to refer primarily to high technology.

It is tempting to call for catching-up enlargement and neighbourhood countries, such as Tunisia and North Macedonia, simply to introduce entrepreneurial-state industrial policies, and to benefit from their access to EU framework policies, such as Horizon 2020 and smart specialisation to do so. While doing so is certainly desirable to facilitate these economies' adjustment to structural change, implementation problems should be expected. In particular, innovation and growth processes are situated within a particular institutional context (Glückler and Bathelt 2017) that is not the same across 
nations or even regions. It is, thus, plausible to expect similar industrial policies to work differently in different contexts. On the policy level, policymaking and implementation processes are likely to prove more difficult in some countries or regions than in others. For a country with a long-term tradition of top-down policymaking currently in a democratic transition process such as Tunisia or for a transformation economy, such as North Macedonia, introducing policy experimentation or risk-taking in the public sector is not an easy task and will require building capacities. In essence, this task boils down to achieving to what (Evans 1995, p. 12) termed "embedded autonomy". Israel's example of an independent and initially peripheral agency, OCS, that was far enough from political interference to be able to experiment over decades (Breznitz and Ornston 2013) could provide some guidance, for instance on how to develop North Macedonia's innovation fund into an agency capable of designing and implementing programmes along an experimental, portfolio-based and risk-taking approach. At the same time, however, accountability and transparency will have to be assured for such an independent agency-a balance that will not be easy to strike in practice. ${ }^{9}$

Precisely to strike this balance is critical because two of the defining criteria of new and entrepreneurial industrial policies, an approach favourable to experimentation and a risk-taking attitude, depend on it. Risk adversity is a common feature of policy design and implementation ${ }^{10}$ and intricately linked to the legitimate and necessary requirement of accountability of government action. Encouraging policy experimentation with public money and justifying partial failures to be expected is a challenge, as will be efforts to align the goal of policy experimentation with bureaucratic procedures meant to ensure accountability when dealing with public money.

It seems that if agencies designing and implementing programmes are to experiment and to make portfolio decisions under uncertainty, they will have to be independent from political inference but at the same time, their accountability when using public funds has to be assured. Accountability does not mean eliminating uncertainty because the whole point about experimentation and portfolio investment by governments is to step in at the point of maximum uncertainty and to reduce risks to levels acceptable for private investors, including through processes of self-discovery whose outcomes are uncertain at the beginning. Therefore, the probabilistic policymaking vision necessary for entrepreneurial industrial policies and the resulting risk-taking approach will almost inevitably lead to some eventually unsuccessful investments. Accountability does not mean preventing these eventual cases of failure. Rather, accountability means firstly investing responsibly according to pre-defined technical criteria, and secondly learning from failure. Doing so presupposes transparent processes and a technical decision-making rationale free from political interference and from the influence of vested interests. In a sense, implementing agencies would need to be held accountable according to similar standards than investment fund managers who cannot rule out negative returns but have to comply with legally defined ethics and transparency standards when carrying out their investment decisions. However, for public agencies, the standards applicable will have to refer to the social rate of return of the investments they make, including the $\mathrm{R}$ and I programmes they design and the implementing decisions they make in carrying out these programmes. Yet, precisely how to define and measure the social rate of return is a complicated question that has to be addressed in more detail in further applied research.

In any case, more research will be useful, in particular on the institutional and governance-related preconditions for the design and implementation of new industrial policies with an entrepreneurial orientation. Specifically, how to ensure the independence of agencies designing and implementing programmes under industrial-policy frameworks, and how to ensure their accountability despite giving them the freedom to experiment and to pursue a portfolio approach is a highly relevant field for further study. We need to better understand what precisely conditions how national or regional governments and their agencies can adopt a more probabilistic and experimental policymaking stance

9 I am grateful to Slavo Radosevic for drawing my attention to the points mentioned in this paragraph.

10 I am grateful to an anonymous reviewer for drawing my attention to the risk adversity of bureaucracies. 
and, thus, make the transition from traditional industrial policies with their top-down thinking to more systemic, entrepreneurial, and facilitating industrial policies.

Further, due to the inherent limitations of the case studies introduced in this article, detailed qualitative empirical research evaluation of past and present policy interventions would be useful. In particular, monitoring and evaluating current policy experiments such as the introduction of the smart specialisation approach in North Macedonia and Tunisia is likely to yield important insights.

On a conceptual level, clarifying the somewhat fuzzy concept of the entrepreneurial state would be useful, for example to understand the precise relationships between experimentation and mission orientation. Doing so could facilitate the appropriate definition of missions in a way that enables experimentation and, thus, help policymakers in using the concept and its envisaged benefits.

In general, lessons and experiences in designing and implementing newer-generation industrial policies based on self-discovery, a facilitating role of government, public-sector risk-taking and portfolio investments according to the idea of the entrepreneurial state can provide an impetus for further improving the long-term effectiveness of industrial policies to drive structural change. Learning from lessons and experiences does not have to take form of one-sided policy transfer from the EU to its neighbourhood. As the case of Israel demonstrates, EU policy can learn from policy experiments made in other countries, but this is not the end of the story. Tunisia's ambitious PMN and pôles de compétitivité programmes can provide lessons for the European discourse on industrial policy, and the experiences the country will make in adopting and adapting the smart specialisation approach to its regions will add to the expertise gathered during the introduction of the approach in European regions during recent years. In the same vein, North Macedonia's smart specialisation process can yield insights on smart specialisation on the national level in small transformation economies, an experience that could be relevant specifically for other transformation economies in the EU's Eastern neighbourhood wishing to adopt the smart specialisation process in the future. Further, innovative policy experimentation under the roof of the innovation fund such as eventual competitive calls for business accelerators (OECD 2018, p. 367) could provide another set of insights for EU industrial policy when it comes to seizing the potentials of newer instruments, such as start-up acceleration. These insights can be valuable to advance the scholarly debate on how to design new industrial policies in an effective and efficient way. At the same time, they could add to the knowledge and expertise available to policymakers in designing policy interventions and to practitioners in implementing them. In particular, they could inform new rounds of policy experimentation and possibly increase the precision of experiments.

Given the start of the new period of EU programmes in 2021, it is likely that the coming two years will see a vibrant debate on how to adjust the major policy frameworks under the EU's industrial policy. For example, the planned mission orientation under Horizon Europe poses questions on how to adapt RIS3 to help regional agents seizing opportunities from participating in mission-oriented research. At the same time, the sheer extent of bottom-up policy experimentation under the smart specialisation approach across Europe, as well as enlargement and neighbourhood countries, will almost certainly yield a wealth of insights comparable to few other experiments in industrial policy. These are exciting times for those seeking to better understand how newer industrial policies can work, and how governments can support entrepreneurial and innovative dynamics in a fast-changing economic and technological environment.

Funding: This research received no external funding.

Conflicts of Interest: The author declares no conflict of interest.

\section{References}

Achy, Lahcen. 2010. Trading High Unemployment for Bad Jobs: Employment Challenges in the Maghreb. Carnegie Papers. Washington: Carnegie Endowment for International Peace, Available online: http://carnegieendowment.org/ files/labor_maghreb.pdf (accessed on 23 April 2019). 
Aiginger, Karl. 2007. Industrial policy: A dying breed or a re-emerging phoenix. Journal of Industry, Competition and Trade 7: 297-323. [CrossRef]

Asheim, Bjørn T., Ron Boschma, and Philip Cooke. 2011. Constructing regional advantage: Platform policies based on related variety and differentiated knowledge bases. Regional Studies 45: 893-904. [CrossRef]

Aubert, Jean-Eric, Tamer Taha, and Anuja Utz. 2013. Local innovation dynamics: Examples and lessons from the Arab world. In The Global Innovation Index: The Local Dyamics of Innovation. Edited by Soumitra Dutta and Bruno Lanvin. Geneva, Ithaca and Fontainebleau: Cornell University, INSEAD, WIPO, pp. 99-106.

Avnimelech, Gil, and Morris Teubal. 2006. Creating venture capital industries that co-evolve with high tech: Insights from an extended industry life cycle perspective of the Israeli experience. Research Policy 35: 1477-98. [CrossRef]

Benner, Maximilian. 2012a. Cluster policy: Principles and a toolbox. SPACES Online 10: 2012-101.

Benner, Maximilian. 2012b. Clusterpolitik: Wege zur Verknüpfung von Theorie und politischer Umsetzung. (Cluster Policy: Ways to Link Theory and Political Implementation). Münster: LIT.

Benner, Maximilian. 2014. From smart specialisation to smart experimentation: Building a new theoretical framework for regional policy of the European Union. Zeitschrift für Wirtschaftsgeographie 58: $33-49$. [CrossRef]

Benner, Maximilian. 2015. Europa und der Maghreb: Von der Nachbarschaft zur Wirtschaftspartnerschaft. (Europe and the Maghreb: From neighborhood to economic partnership). In The Southern Mediterranean: Challenges to the European Foreign and Security Policy. Edited by Beate Neuss and Antje Nötzold. Baden-Baden: Nomos, pp. 57-82.

Benner, Maximilian. 2018. Smart specialization and institutional context: Towards a process of institutional discovery and change. Papers in Econ. Geogr. Innov. Stud. 3.

Benner, Maximilian. 2019. A New Arab Social Contract? Institutional Perspectives for Economic Reform in Arab Countries. Cham: Springer.

Benner, Maximilian, Bieringer Lukas, Matthias Knaupp, Jana Wittemaier, and Adrian Wruck. 2016. Towards a Smart Specialization Strategy for Haifa. MPRA Paper No. 73299. Munich: University Library of Munich.

Benner, Maximilian. forthcoming. Cluster policy in Tunisia: From institutional voids to smart specialization. In African Development Perspectives Yearbook 2018: Science, Technology and Innovation Policies for Inclusive Growth in Africa. Edited by Tobias Knedlik and Karl Wohlmuth. Münster: LIT.

Breznitz, Dan, and Darius Ornston. 2013. The revolutionary power of peripheral agencies: Explaining radical policy innovation in Finland and Israel. Comparative Political Studies 46: 1219-45. [CrossRef]

Brösse, Ulrich. 1999. Industriepolitik (Industrial Policy), 2nd ed. Munich: Oldenburg.

Cammett, Melani. 2007. Business-government relations and industrial change: The politics of upgrading in Morocco and Tunisia. World Development 35: 1889-903. [CrossRef]

Chen, Tain-Jy, Been-Lon Chen, and Yun-Peng Chu. 2001. The development of Taiwan's electronics industry. In Industrial Policy, Innovation and Economic Growth: The Experience of Japan and the Asian NIEs. Edited by Poh-Kam Wong and Chee-Yuen Ng. Singapore: Singapore University Press, pp. 245-82.

Chiu, Stephen W. K., and Tai-Lok Lui. 2001. The Hong Kong model of development revisited. In Industrial Policy, Innovation and Economic Growth: The Experience of Japan and the Asian NIEs. Edited by Poh-Kam Wong and Chee-Yuen Ng. Singapore: Singapore University Press, pp. 431-59.

Chu, Yun-Peng, Tain-Jy Chen, and Been-Lon Chen. 2001. Rethinking the development paradigm: Lessons from Taiwan: The optimal degree of state intervention. In Industrial Policy, Innovation and Economic Growth: The Experience of Japan and the Asian NIEs. Edited by Poh-Kam Wong and Chee-Yuen Ng. Singapore: Singapore University Press, pp. 197-244.

Cimoli, Mario, Giovanni Dosi, and Joseph E. Stiglitz. 2015. The rationale for industrial and innovation policy. Internomics 50: 126-32.

Conrad, Markus. 1987. Industriepolitik als wirtschaftspolitische Option in der Sozialen Marktwirtschaft: Ein ordnungspolitisches industriepolitisches Konzept für die Bundesrepublik Deutschland (Industrial Policy and Option of Economic Policy in the Social Market Economy: A Market-Policy Concept of Industrial Policy for the Federal Republic of Germany). Hamburg: Kovač.

Delegation of the European Union to Israel, ed. 2016. Agreements. Available online: http://eeas.europa.eu/archives/ delegations/israel/eu_israel/political_relations/agreements/index_en.htm (accessed on 21 March 2019). 
Diop, Ndiamé, and Sofiane Ghali. 2012. Are Jordan and Tunisia's Exports Becoming More Technologically Sophisticated? Analysis Using Highly Disaggregated Export Databases. World Bank Middle East and North Africa Working Paper Series, No. 54; Washington: The World Bank.

Erdle, Steffen. 2011. Industrial Policy in Tunisia. DIE Discussion Paper, 1/2011. Bonn: Deutsches Institut für Entwicklungspolitik.

European Commission, ed. 2010a. A Digital Agenda for Europe. Brussels: Communication from the Commission to the European Parliament, the Council, the European Economic and Social Committee and the Committee of Regions, August 19.

European Commission, ed. 2010b. An Integrated Industrial Policy for the Globalisation Era: Putting Competitiveness and Sustainability at Centre Stage. Brussels: Communication from the Commission to the European Parliament, the Council, the European Economic and Social Committee and the Committee of Regions, October 28.

European Commission, ed. 2010c. Europe 2020: A Strategy for Smart, Sustainable and Inclusive Growth. Brussels: Communication from the Commission, March 3.

European Commission, ed. 2010d. Europe 2020 Flagship Initiative: Innovation Union. Brussels: Communication from the Commission to the European Parliament, the Council, the European Economic and Social Committee and the Committee of Regions, October 6.

European Commission, ed. 2017. Investing in a Smart, Innovative and Sustainable Industry: A Renewed EU Industrial Policy Strategy. Brussels: Communication from the Commission to the European Parliament, the European Council, the Council, the European Economic and Social Committee, the Committee of Regions and the European Investment Bank, September 13.

European Commission, ed. 2018a. Commission Staff Working Document: The Former Yugoslav Republic of Macedonia 2018 Report. Strasbourg: European Commission, April 17.

European Commission, ed. 2018b. Proposal for a Regulation of the European Parliament and of the Council Establishing Horizon Europe-The Framework Programme for Research and Innovation, Laying Down Its Rules for Participation and Dissemination. Brussels: European Commissio, June 7.

European Commission, ed. 2018c. Trade: Policy: Countries and Regions: Tunisia. Available online: http: //ec.europa.eu/trade/policy/countries-and-regions/countries/tunisia (accessed on 25 March 2019).

European Commission, ed. 2019. Associated Countries. Available online: http://ec.europa.eu/research/participants/ data/ref/h2020/grants_manual/hi/3cpart/h2020-hi-list-ac_en.pdf (accessed on 21 March 2019).

Evans, Peter. 1995. Embedded Autonomy: States \& Industrial Transformation. Princeton: Princeton University Press. Fernández Cuesta, Gaspar. 2019. La industria y sus especios (Industry and its spaces). In Atlas de Geografía Humana de España (Atlas of Human Geography in Spain). Edited by Gaspar Fernández Cuesta. Madrid: Paraninfo, pp. 235-303.

Foray, Dominique. 2017. The economic fundamentals of smart specialization strategies. In Advances in the Theory and Practice of Smart Specialization. Edited by Slavo Radosevic, Adrian Curaj, Gheorgiu Radu, Riviu Andreescu and Imogen Wage. London: Elsevier, pp. 38-52.

Foray, Dominique, and Bart Van Ark. 2007. Smart Specialisation in a Truly Integrated Research Area Is the Key to Attracting More $R$ and $D$ to Europe. Knowledge Economists Policy Brief No. 1. Brussels: European Commission.

Foray, Dominique, Paul A. David, and Bronwyn Hall. 2009. Smart Specialization-The Concept. Knowledge Economists Policy Brief No. 9. Brussels: European Commission.

Foray, Dominique, John Goddard, Goenaga Beldarrain, Landabaso Xabier, McCann Mikel, Morgan Philip, Nauwelaers Claire Kevin, and Raquel Ortega-Argilés. 2012. Guide to Research and Innovation Strategies for Smart Specialisation (RIS 3). Luxembourg: Publications Office of the European Union.

Garcia-Torres, Abraham. 2016. JRC Science for Policy Report: RIO Country Report 2015: Israel. Seville: Joint Research Centre.

Ghali, Sofiane, and Ssami Rezgui. 2015. Structural transformation and industrial policy in selected Southern Mediterranean countries: Tunisia. In Structural Transformation and Industrial Policy: A Comparative Analysis of Egypt, Morocco, Tunisia and Turkey and Case Studies. Edited by Forum Euroméditerranéen des Instituts de Sciences Économiques. Luxembourg: European Investment Bank, pp. 39-68.

Glückler, Johannes, and Harald Bathelt. 2017. Institutional context and innovation. In The Elgar Companion to Innovation and Knowledge Creation. Edited by Harald Bathelt, Patrick Cohendet, Sebastian Henn and Laurent Simon. Cheltenham: Elgar, pp. 121-37. 
Hausmann, Ricardo, and Dani Rodrik. 2003. Economic development as self-discovery. Journal of Development Economics 72: 603-33. [CrossRef]

Hazboun, Waleed. 2008. Beaches, Ruins, Resorts: The Politics of Tourism in the Arab World. Minneapolis: University of Minnesota Press.

Josimovski, Sasho. 2014. ERAWATCH Country Reports 2013: Former Yugoslav Republic of Macedonia. Seville: Joint Research Centre.

Kang, Hojin. 2001. The development experience of South Korea: The role of public policy. In Industrial Policy, Innovation and Economic Growth: The Experience of Japan and the Asian NIEs. Edited by Poh-Kam Wong and Chee-Yuen Ng. Singapore: Singapore University Press, pp. 323-96.

Kroll, Henning. 2015. Efforts to implement smart specialization in practice-Leading unlike horses to the water. European Planning Studies 23: 2079-98. [CrossRef]

Landesmann, Michael A. 2015. Industrial policy: Its role in the European economy. Internomics 50: $133-38$.

Lehmann, Tine, and Maximilian Benner. 2015. Cluster policy in the light of institutional context: A comparative study of transition countries. Administrative Sciences 5: 188-212. [CrossRef]

M'Henni, Hatem, Adel Ben Youssef, Nawsheen Elaheebocus, and Ludovic Ragni. 2013. Are Technoparks High Tech Fantasies? Lessons from the Tunisian Experience. MPRA Paper No. 46183. Nice: European Review of Industrial Economics and Policy.

M'Henni, Hatem, and Dimitris Deniozos. 2013. ERAWATCH Country Reports 2012: Tunisia. Brussels: European Commission.

Matusiak, Monika, and Alexander Kleibrink, eds. 2018. Supporting an Innovation Agenda for the Western Balkans: Tools and Methodologies. Luxembourg: Publications Office of the European Union.

Mazzucato, Mariana. 2011. The entrepreneurial state. Soundings 49: 131-42. [CrossRef]

Mazzucato, Mariana. 2013. The Entrepreneurial State: Debunking Public vs. Private Sector Myths. London and New York: Anthem Press.

Mazzucato, Mariana. 2015. Which industrial policy does Europe need? Internomics 50: 120-25. [CrossRef]

Mazzucato, Mariana. 2018. Mission-Oriented Research \& Innovation in the European Union: A Problem-Solving Approach to Fuel Innovation-Led Growth. Luxembourg: Publications Office of the European Union.

McCann, Philip, and Raquel Ortega-Argilés. 2015. Smart specialization, regional growth and applications to European Union cohesion policy. Regional Studies 49: 1291-302. [CrossRef]

Meyer-Stamer, Jörg. 2009. Moderne Industriepolitik oder postmoderne Industriepolitiken? (Modern Industrial Policy or Postmodern Industrial Policies?). In Schriftenreihe Moderne Industriepolitik 1/2009. Berlin: Friedrich-Ebert-Stiftung.

Murphy, Emma C. 2006. The Tunisian mise à niveau programme and the political economy of reform. New Political Economy 11: 519-40. [CrossRef]

Organisation for Economic Co-operation and Development, ed. 2018. Competitiveness in South East Europe: A Policy Outlook 2018. Paris: Organisation for Economic Co-operation and Development.

Organisation for Economic Co-operation and Development, and European Commission, and Eurostat, eds. 1997. The Measurement of Scientific and Technological Activities: Proposed Guidelines for Collecting and Interpreting Technological Innovation Data: Oslo Manual. Paris: Organisation for Economic Co-operation and Development.

Page, Tim. 2015. A European industrial policy for the new global economy. Internomics 50: 152-55.

Pianta, Mario. 2015. What is to be produces? The case for industrial policy. Internomics 50: 139-45.

Porter, Michael E. 1990. The Competitive Advantage of Nations. Reprint 1998. New York: Free Press.

Radosevic, Slavo. 2017a. Assessing EU smart specialization policy in a comparative perspective. In Advances in the Theory and Practice of Smart Specialization. Edited by Slavo Radosevic, Adrian Curaj, Radu Gheorgiu, Riviu Andreescu and Imogen Wage. London: Elsevier, pp. 2-37.

Radosevic, Slavo. 2017b. Advancing theory and practice of smart specialization: Key messages. In Advances in the Theory and Practice of Smart Specialization. Edited by Slavo Radosevic, Adrian Curaj, Radu Gheorgiu, Riviu Andreescu and Imogen Wage. London: Elsevier, pp. 346-56.

Richards, Alan, and John Waterbury. 2008. A Political Economy of the Middle East, 3rd ed. Boulder: Westview Press. Rivlin, Paul. 2009. Arab Economies in the Twenty-First Century. New York: Cambridge University Press.

Rodríguez-Pose, Andrés, and Daniel Hardy. 2014. Technology and Industrial Parks in Emerging Countries: Panacea or Pipedream? Cham, Heidelberg, New York, Dordrecht and London: Springer.

Rodrik, Dani. 2009. Industrial policy: Don't ask why, ask how. Middle East Development Journal 1: 1-29. [CrossRef] 
Seitz, Michael J. 2000. Staatliche Industriepolitik: Begründungen, Instrumente und Probleme (Governmental Industrial Policy: Justifications, Instruments, and Problems). Baden-Baden: Nomos.

Trajtenberg, Manuel. 2001. Innovation in Israel 1968-97: A comparative analysis using patent data. Research Policy 30: 363-89. [CrossRef]

Trajtenberg, Manuel. 2002. Government support for commercial R and D: Lessons from the Israeli experience. Innovation Policy and the Economy 2: 79-134. [CrossRef]

Trippl, Michaela, Elena Zukauskaite, and Adrian Healy. 2018. Shaping smart specialisation: The role of place-specific factors in advanced, intermediate and less-developed European regions. Regional Studies, 1-13.

Von Einem, Eberhard. 1991. Industriepolitik: Anmerkungen zu einem kontroversen Begriff (Industrial Policy: Remarks on a Controversial Notion). In Industriepolitische Strategien: Bundesländer im Vergleich (Industrial Strategies: Länder in Comparison). Edited by Ulrich Jürgens and Wolfgang Krumbein. Berlin: Sigma, pp. 11-33.

Waterbury, John. 1999. The long gestation and brief triumph of import-substituting industrialization. World Development 27: 323-41. [CrossRef]

Wong, Poh-Kam. 2001. The role of the state in Singapore's industrial development. In Industrial Policy, Innovation and Economic Growth: The Experience of Japan and the Asian NIEs. Edited by Poh-Kam Wong and Chee-Yuen Ng. Singapore: Singapore University Press, pp. 503-79.

Wong, Poh-Kam, and Chee-Yuen Ng. 2001. Rethinking the development paradigm: lessons from Japan and the four Asian NIEs. In Industrial Policy, Innovation and Economic Growth: The Experience of Japan and the Asian NIEs. Edited by Poh-Kam Wong and Chee-Yuen Ng. Singapore: Singapore University Press, pp. 1-54.

Wonglimpiyarat, Jarunee. 2016. Government policies towards Israel's high-tech powerhouse. Technovation 52-53: 18-27. [CrossRef]

World Bank, ed. 1993. The East Asian Miracle: Economic Growth and Public Policy. Oxford: Oxford University Press. World Bank, ed. 2014. The Unfinished Revolution: Bringing Opportunity, Good Jobs and Greater Wealth to All Tunisians. Washington, D.C.: The World Bank.

(C) 2019 by the author. Licensee MDPI, Basel, Switzerland. This article is an open access article distributed under the terms and conditions of the Creative Commons Attribution (CC BY) license (http://creativecommons.org/licenses/by/4.0/). 